\title{
Front Matter: Volume 8218
}

, "Front Matter: Volume 8218," Proc. SPIE 8218, Optical Fibers and Sensors for Medical Diagnostics and Treatment Applications XII, 821801 (19 March 2012); doi: 10.1117/12.928227

SPIE. Event: SPIE BiOS, 2012, San Francisco, California, United States 


\section{PROGRESS IN BIOMEDICAL OPTICS AND IMAGING}

Vol. 13, No. 12

\section{Optical Fibers and Sensors for Medical Diagnostics and Treatment Applications XII}

Israel Gannot

Editor

21-22 January 2012

San Francisco, California, United States

Sponsored and Published by

SPIE

Volume 8218 
The papers included in this volume were part of the technical conference cited on the cover and title page. Papers were selected and subject to review by the editors and conference program committee. Some conference presentations may not be available for publication. The papers published in these proceedings reflect the work and thoughts of the authors and are published herein as submitted. The publisher is not responsible for the validity of the information or for any outcomes resulting from reliance thereon.

Please use the following format to cite material from this book:

Author(s), "Title of Paper," in Optical Fibers and Sensors for Medical Diagnostics and Treatment Applications XII, edited by Israel Gannot, Proceedings of SPIE Vol. 8218 (SPIE, Bellingham, WA, 2012) Article CID Number.

ISSN 1605-7422

ISBN 9780819488619

Published by

SPIE

P.O. Box 10, Bellingham, Washington 98227-0010 USA

Telephone +1 3606763290 (Pacific Time) · Fax +1 3606471445

SPIE.org

Copyright (C) 2012, Society of Photo-Optical Instrumentation Engineers.

Copying of material in this book for internal or personal use, or for the internal or personal use of specific clients, beyond the fair use provisions granted by the U.S. Copyright Law is authorized by SPIE subject to payment of copying fees. The Transactional Reporting Service base fee for this volume is $\$ 18.00$ per article (or portion thereof), which should be paid directly to the Copyright Clearance Center (CCC), 222 Rosewood Drive, Danvers, MA 01923. Payment may also be made electronically through CCC Online at copyright.com. Other copying for republication, resale, advertising or promotion, or any form of systematic or multiple reproduction of any material in this book is prohibited except with permission in writing from the publisher. The CCC fee code is 1605$7422 / 12 / \$ 18.00$.

Printed in the United States of America.

Publication of record for individual papers is online in the SPIE Digital Library.

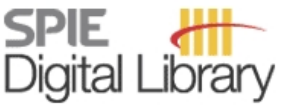

SPIEDigitallibrary.org

Paper Numbering: Proceedings of SPIE follow an e-First publication model, with papers published first online and then in print and on CD-ROM. Papers are published as they are submitted and meet publication criteria. A unique, consistent, permanent citation identifier (CID) number is assigned to each article at the time of the first publication. Utilization of CIDs allows articles to be fully citable as soon as they are published online, and connects the same identifier to all online, print, and electronic versions of the publication. SPIE uses a six-digit CID article numbering system in which:

- The first four digits correspond to the SPIE volume number.

- The last two digits indicate publication order within the volume using a Base 36 numbering system employing both numerals and letters. These two-number sets start with 00, 01, 02, 03, 04, $05,06,07,08,09,0 A, 0 B \ldots$. 0Z, followed by 10-1Z, 20-2Z, etc.

The CID number appears on each page of the manuscript. The complete citation is used on the first page, and an abbreviated version on subsequent pages. Numbers in the index correspond to the last two digits of the six-digit CID number. 


\section{Contents}

vii Conference Committee

SESSION I

821802 Investigation of tapered silver / silver halide coated hollow glass waveguides for the transmission of $\mathrm{CO}_{2}$ laser radiation [8218-01]

C. M. Bledt, D. V. Kopp, J. A. Harrington, Rutgers Univ. (United States); S. Kino, Y. Matsuura, Tohoku Univ. (Japan); J. M. Kriesel, Opto-Knowledge Systems, Inc. (United States)

821803 Novel microsphere chain fiber tips for use in mid-infrared ophthalmic laser surgery [8218-02] T. C. Hutchens, A. Darafsheh, The Univ. of North Carolina at Charlotte (United States); A. Fardad, PhotonTech (United States); A. N. Antoszyk, Charlotte Eye, Ear, Nose and Throat Associates (United States); H. S. Ying, Johns Hopkins Medical Institutions (United States); V. N. Astratov, N. M. Fried, The Univ. of North Carolina at Charlotte (United States)

821804 Uniform polymer-film formation in 100- $\mu \mathrm{m}$-bore hollow fiber for Er:YAG laser transmission [8218-03]

K. Iwai, M. Suzuki, Sendai National College of Technology (Japan); M. Miyagi, School Corp. of Tohoku Gakuin (Japan); Y.-W. Shi, Fudan Univ. (China); Y. Matsuura, Tohoku Univ. (Japan)

821805 Fabrication of silica hollow core photonic crystal fibres for Er:YAG surgical applications [8218-04]

A. Urich, R. R. J. Maier, Heriot-Watt Univ. (United Kingdom); J. C. Knight, B. J. Mangan, S. Renshaw, Univ. of Bath (United Kingdom); D. P. Hand, J. D. Shephard, Heriot-Watt Univ. (United Kingdom)

821807 Picoliter-volume glucose concentration microsensor based on miniature abrupt-tapered Mach-Zehnder-interferometer [8218-06]

Z.-Z. Feng, T.-H. Yang, N.-K. Chen, Y.-N. Chen, National United Univ. (Taiwan); Y.-C. Chang, National Changhua Univ. of Education (Taiwan)

SESSION II

821808 Raman spectral imaging using hollow flexible fiber bundles [8218-07]

T. Tomiyama, T. Katagiri, Y. Matsuura, Tohoku Univ. (Japan)

821809 Silver and silver / polystyrene coated hollow glass waveguides for the transmission of visible and infrared radiation [8218-08]

C. M. Bledt, J. A. Harrington, Rutgers Univ. (United States) 
$82180 \mathrm{~A}$ Lifetime prediction for $\mathbf{4 0 5}-\mathrm{nm}$ single-mode delivery systems for therapeutic laser applications [8218-09]

C. P. Gonschior, Technische Hochschule Mittelhessen (Germany) and City Univ. London (United Kingdom); K.-F. Klein, Technische Hochschule Mittelhessen (Germany); T. Sun,

K. T. V. Grattan, City Univ. London (United Kingdom); M. R. Kirshenbaum, E. J. Seibel, Univ. of Washington (United States)

$8218 \mathrm{OB}$ Image-guided intervention in the human bile duct using scanning fiber endoscope system [8218-10]

E. J. Seibel, Univ. of Washington (United States); J. A. Jo, Texas A\&M Univ. (United States);

C. D. Melville, R. S. Johnston, C. R. Naumann, M. D. Saunders, Univ. of Washington (United States)

$82180 \mathrm{C}$ Infrared spectral imaging by hollow-optical fiber bundle [8218-11]

C. Huang, S. Kino, T. Katagiri, Y. Matsuura, Tohoku Univ. (Japan)

$82180 \mathrm{D} \quad$ Photothermal imaging bundle system for estimating tissue oxygen saturation [8218-12]

Y. Milstein, Tel Aviv Univ. (Israel); D. M. Allon, Rabin Medical Ctr. (Israel); J. Harrington,

C. Bledt, Rutgers Univ. (United States); I. Gannot, Tel Aviv Univ. (Israel)

\section{SESSION III}

$82180 \mathrm{O} \quad$ Small-diameter hollow waveguides based on silver-clad stainless steel tube for infrared laser light transmission [8218-13]

A. Hongo, M. Ohkawa, N. Shiina, S. Sato, Hitachi Cable, Ltd. (Japan)

8218 OF Effects of high humidity and high temperature on failure of optical fiber for high-power delivery [8218-14]

X. Sun, L. Huang, J. Li, OFS Specialty Photonics Div. (United States)

$82180 \mathrm{G}$ Metal-assisted guided-mode resonance device for biosensing [8218-15]

S.-F. Lin, W.-Y. Chen, J.-Y. Chang, National Central Univ. (Taiwan)

$8218 \mathrm{OH} \quad$ Multilayer silver / dielectric thin-film coated hollow waveguides for sensor and laser power delivery applications [8218-16]

C. M. Bledt, J. A. Harrington, Rutgers Univ. (United States); J. M. Kriesel, Opto-Knowledge Systems, Inc. (United States)

\section{SESSION IV}

$82180 \mathrm{~J}$ Design and fabrication of hollow fiber-based Raman tweezers for bioparticle measurement [8218-18]

Y. Morisaki, T. Katagiri, Y. Matsuura, Tohoku Univ. (Japan)

$8218 \mathrm{OL}$ Highly birefringent terahertz hollow fiber: design, fabrication, and experimental characterization [8218-21]

X.-L. Tang, B.-S. Sun, Y.-W. Shi, Fudan Univ. (China) 
$82180 \mathrm{M}$ Excitation and lasing of whispering gallery modes in dye doped microspheres at the tip of a microstructured optical fiber and application for a sensitive dip sensor architecture [8218-22]

K. J. Rowland, A. François, T. M. Monro, The Univ. of Adelaide (Australia)

8218 ON Label-free DNA biosensor based on doubled tilted fiber Bragg grating [8218-23]

A. Candiani, M. Sozzi, A. Cucinotta, S. Selleri, R. Veneziano, R. Corradini, R. Marchelli, Univ. of Parma (Italy); P. Childs, S. Pissadakis, Foundation for Research and Technology-Hellas (Greece)

821800 Miniature fiber-optic force sensor for vitreoretinal microsurgery based on low-coherence Fabry-Pérot interferometry [8218-24]

X. Liu, I. I. Iordachita, X. He, R. H. Taylor, J. U. Kang, The Johns Hopkins Univ. (United States)

8218 OP Dispersive Fourier transform using few-mode fibers for real-time and high-speed spectroscopy [8218-25]

Y. Qiu, C. Zhang, K. K. Y. Wong, K. K. Tsia, The Univ. of Hong Kong (Hong Kong, China)

$82180 Q \quad$ Optimal design for hollow fiber inner-coated by dielectric layers with surface roughness [8218-26]

B.-S. Sun, X.-L. Tang, Y.-W. Shi, Fudan Univ. (China); K. Iwai, Sendai National College of Technology (Japan); M. Miyagi, School Corp. of Tohoku Gakuin (Japan)

$8218 \mathrm{OR} \quad \mathrm{Dy}: \mathrm{PbGa}_{2} \mathrm{~S}_{4}$ laser radiation and its delivery by hollow waveguide [8218-27]

H. Jelínková, M. Nĕmec, Czech Technical Univ. in Prague (Czech Republic); M. Miyagi,

K. Iwai, H. Takaku, Sendai National College of Technology (Japan); M. Doroshenko,

T. T. Basiev, A. M. Prokhorov General Physics Institute (Russian Federation); V. V. Badikov,

D. V. Badikov, Kuban State Technological Univ. (Russian Federation)

\section{SESSION VI}

8218 OT Broadband ATR-sensor with variable path lengths [8218-29]

K.-F. Klein, Technische Hochschule Mittelhessen (Germany) and TransMIT GmbH (Germany); S. Pandey, P. Dahal, Technische Hochschule Mittelhessen (Germany); M. Klein, TransMIT GmbH (Germany); M. Belz, World Precision Instruments Inc. (United States); G. Hillrichs, Hochschule Merseburg (Germany)

8218 OU Behavior of polymer cladding materials under extremely high temperatures [8218-30] T. E. Clark, SSCP USA (United States); S. Chang, S. Kwak, J. H. Oh, SSCP Co., Ltd. (Korea, Republic of)

$82180 \mathrm{~V}$ Fiber optic based heart-rate and pulse pressure shape monitor [8218-31]

D. Kokkinos, S. Dehipawala, T. Holden, E. Cheung, M. Musa, G. Tremberger, Jr., P. Schneider,

D. Lieberman, T. Cheung, Queensborough Community College (United States) 
$82180 \mathrm{~W}$ Force sensing micro-forceps with integrated fiber Bragg grating for vitreoretinal surgery [8218-32]

X. He, M. A. Balicki, J. U. Kang, The Johns Hopkins Univ. (United States); P. L. Gehlbach, J. T. Handa, The Wilmer Eye Institute at Johns Hopkins (United States); R. H. Taylor,

I. I. Iordachita, The Johns Hopkins Univ. (United States)

8218 0X Portable fiber optic ballistocardiogram sensor for home use [8218-33]

Z. Chen, J. T. Teo, S. H. Ng, X. Yang, Institute for Infocomm Research (Singapore)

8218 oY Chalcogenide glass fibreoptics for new mid-infrared medical endoscopy [8218-34]

A. B. Seddon, The Univ. of Nottingham (United Kingdom)

\section{POSTER SESSION}

$82180 Z$ An implantable fiber-optic surface plasmon resonance glucose sensor based on LPFG [8218-19]

D. Li, R. Zhu, P. Wu, J. Yang, K. Xu, Tianjin Univ. (China)

Author Index 


\title{
Conference Committee
}

\author{
Symposium Chairs \\ James G. Fujimoto, Massachusetts Institute of Technology \\ (United States) \\ R. Rox Anderson, Wellman Center for Photomedicine, Massachusetts \\ General Hospital, Harvard School of Medicine (United States)
}

Program Track Chairs

Taun Vo-Dinh, Duke University (United States)

Anita Mahadevan-Jansen, Vanderbilt University (United States)

Conference Chair

Israel Gannot, Tel Aviv University (Israel)

Program Committee

James P. Clarkin, Polymicro Technologies, A Subsidiary of Molex Inc. (United States)

Ilko K. Ilev, U.S. Food and Drug Administration (United States)

Jin Ung Kang, The Johns Hopkins University (United States)

Karl-Friedrich Klein, Technsiche Hochschule Mittelhessen (Germany)

Pierre Lucas, The University of Arizona (United States)

Yuji Matsuura, Tohoku University (Japan)

Session Chairs

Session I

Israel Gannot, Tel Aviv University (Israel)

Session II

James P. Clarkin, Polymicro Technologies, A Subsidiary of Molex

Incorporated (United States)

Session III

Pierre Lucas, The University of Arizona (United States)

Session IV

Jin Ung Kang, The Johns Hopkins University (United States)

Session $V$

Yuji Matsuura, Tohoku University (Japan) 
Session $\mathrm{VI}$

Ilko K. llev, U.S. Food and Drug Administration (United States) 